\title{
EFEKTIVITAS PELAYANAN PUBLIK PADA DINAS KEPENDUDUKAN DAN PENCATATAN SIPIL KABUPATEN SOPPENG
}

\section{EFFECTIVENESS OF PUBLIC SERVICES AT THE POPULATION AND CIVIL REGISTRY OFFICE IN SOPPENG REGENCY}

\author{
Risma Niswaty, A. Muhammad Fajar Maualana, Jamaluddin, \\ Muhammad Darwis, Rudi Salam \\ Pendidikan Administrasi Perkantoran, Universitas Negeri Makassar \\ Jl. A. P. Pettarani, Tidung, Kota Makassar \\ E-mail: risma.niswaty@unm.ac.id
}

Naskah diterima tanggal 22 April 2020. Naskah direvisi tanggal 10 Juli 2020.

Naskah disetujui tanggal 28 Juli 2020

\begin{abstract}
Abstrak
Penelitian ini memiliki tujuan untuk mengetahui efektifitas pelayanan publik pada Dinas Kependudukan dan Pencatatan Sipil Kabupaten Soppeng. Penelitian ini merupakan penelitian deskriptif dengan menggunakan pendekatan kualitatif. Dalam penelitian ini teknik pengumpulan data yang digunakan adalah teknik observasi, wawancara, dan dokumentasi. Informan penelitian adalah Kepala Dinas Kependudukan dan Pencatatan Sipil Kabuapten Soppeng, petugas pemberi pelayanan Dinas Kependudukan dan Pencatatan Sipil sebanyak 3 orang, dan masyarakat yang sedang mengurus administrasi kependudukan di Dinas Kependudukan dan Pencatatan Sipil Kabupaten Soppeng sebanyak 3 orang. Teknik pemeriksaan keabsahan data yang digunakan dalam penelitian ini yaitu teknik trianggulasi sumber. Adapun teknik analisis data yang digunakan dalam penelitian ini adalah model interaktif. Berdasarkan hasil penelitian memperlihatkan bahwa efektifitas pelayanan publik pada Dinas Kependudukan dan Pencatatan Sipil Kabupaten Soppeng dilihat dari: 1) standar prosedur pelayanan, 2) waktu penyelesaian, 3) biaya pelayanan, 4) produk pelayanan, 5) sarana dan prasarana, dan 6) kompetensi petugas pemberi pelayanan. Dari 6 inidkator pengukuran efektivitas pelayanan public yang ditampilkan terlihat ada 4 indikator yang efektif. Inilah kemudian ditarik kesimpulan pelayanan public di Disdukcapil sudah efektif walaupun ada beberapa saran perbaikannya. Pelayanan public di Disdukcapil "telah terlaksana dengan efektif namun dengan beberapa rekomendasi perbaikan".
\end{abstract}

Kata Kunci: Efektifitas, Pelayanan Publik, SOP

\section{Abstract}

This study aims to determine the effectiveness of public services at the Population and Civil Registry Office of Soppeng Regency. This research is a descriptive study using a qualitative approach. In this study the data collection techniques used were observation, interview, and documentation techniques. The informants of the research are the Head of Population and Civil Registration Office of Sukareng Regency, 3 people who provide the population and civil registry service providers, and the people who are taking care of population administration in the Soppeng Regency Population and Civil Registration Service. The data validity checking technique used in this study is the source triangulation technique. The data analysis technique used in this study is an interactive model. Based on the results of the study showed that the effectiveness of public services at the Department of Population and Civil Registration Soppeng Regency seen from: 1) standard service procedures, 2) completion time, 3) service costs, 4) service products, 5) facilities and infrastructure, and 6) competence service provider. From the 6 indicators that measure the effectiveness of public services shown, there are 4 effective indicators. This then concluded the public service in Disdukcapil has been effective even though there are some suggestions for improvement. Public services at Disdukcapil "have been carried out effectively but with some recommendations for improvement".

Keywords: Effectiveness, Public Services, SOP. 


\section{PENDAHULUAN}

Pelayanan publik adalah rangkaian kegiatan dalam rangka pemenuhan kebutuhan pelayanan sesuai dengan peraturan perundang-undangan bagi setiap warga negara dan penduduk atas barang, jasa dan / atau pelayanan administratif yang disediakan oleh penyelenggara pelayanan publik (Akib \& Salam, 2016; Isma et al., 2017; Mirdawati et al., 2018; Saggaf et al., 2014). Seiring dengan dijalankannya kebijakan publik, aparatur pemerintah daerah dapat menyelenggarakan pelayanan publik yang lebih baik dan efektif yang sesuai dengan kebutuhan masyarakat diwilayahnya masing-masing(Jamaluddin et al., 2017; Sedarmayanti, 2017; Sunusi, 2016; Wardhani et al., 2016). Namun, melihat realita yang terjadi di lapangan penyelenggaraan pelayanan publik yang dilaksanakan oleh pemerintah masih tampak kurang baik dan kurang efektif ditambah kinerja para pelaksananya yang belum profesional. Hal ini terlihat masih banyaknya masyarakat yang merasa tidak puas bahkan tidak terlayani dengan baik pada saat mengurus dokumen administrasi kependudukan. Untuk itu peningkatan kualitas pelayanan publik sangat diperlukan.

Peningkatan kualitas pelayanan publik sangat diperlukan bahkan sangat penting (Akib \& Salam, 2016; Dahlan et al., 2017; Isma et al., 2017; Nur, 2017; Rizqulloh \& Elida, 2015). Hal ini terjadi karena adanya tuntutan masyarakat terhadap kualitas pelayanan yang baik, akan tetapi penyelenggaraan pelayanan publik yang dilakukan oleh pemerintah tidak mengalami perubahan yang berarti. Untuk itu perlu penerapan pelayanan publik yang dilaksanakan pada lembaga swasta diterapkan ke dalam birokrasi pemerintahan yang dikenal dengan istilah reinventing government. Osborne menyatakan bahwa "reinventing government itu pada hakikatnya adalah upaya untuk mentransformasikan jiwa dan kinerja wiraswasta (entrepreneurship) ke dalam birokrasi pemerintah".

Pemerintah sebagai pihak yang bertanggung jawab menyediakan pelayanan publik yang dibutuhkan oleh masyarakat harus terus berupaya dalam memberikan pelayanan yang terbaik demi terciptanya peningkatan kualitas pelayanan publik (Astuti \& Amalah, 2020). Kepuasan masyarakat disisi lain merupakan tolak ukur dari terciptanya keberhasilan pelayanan publik yang diberikan oleh lembaga yang bertugas memberikan pelayanan kepada masyarakat, oleh karena itu segala bentuk pelayanan publik harus senantiasa difokuskan pemenuhan pelayanan kepada masyarakat baik dari segi kualitas maupun kuantitasnya (Haprabu et al., 2020; Labiran, 2013; Sunarsi \& Baharuddin, 2019).

Berdasarkan Undang-Undang RI Nomor 25 Tahun 2009 tentang Pelayanan Publik, BAB V Penyelenggaraan Pelayanan Publik bagian kesatu Standar Pelayanan pasal 20 ayat 1; "Penyelenggara berkewajiban menyusun dan menetapkan standar pelayanan dengan memperhatikan kemampuan penyelenggara, kebutuhan masyarakat, dan kondisi lingkungan". Untuk itu diharapkan kepada seluruh aparatur pemerintah baik yang berada di pusat maupun di daerah agar melaksanakan pelayanan publik dengan baik sesuai yang diharapkan oleh seluruh lapisan masyarakat. Masih banyak yang harus dibenahi dari pelayanan publik di Negara Indonesia ini dan tidak menutup kemungkinan salah satu dari pelaksana pelayanan publik tersebut yaitu di wilayah Kabupaten Soppeng tepatnya Dinas Kependudukan dan Pencatatan Sipil Kabupaten Soppeng.

Kabupaten Soppeng merupakan salah satu Kabupaten yang berada di wilayah Propinsi Sulawesi Selatan yang dalam pelaksanaan pelayanan publik di bidang administrasi kependudukan dikelola oleh Dinas Kependudukan dan Pencatatan Sipil Kabupaten Soppeng. Pelayanan publik yang meliputi administrasi kependudukan yang sering dilakukan oleh masyarakat diantaranya pembuatan Kartu Keluarga (KK), Kartu Tanda Penduduk Elektronik (e-KTP), Akte Kelahiran dan lain sebagainya. Namun dalam pelaksanaan pelayanan publik pada 
Dinas Kependudukan dan Pencatatan Sipil Kabupaten Soppeng ini sering terjadi pelayanan publik yang kurang memuaskan.

Berdasarkan pemberitaan media Trans Sulawesi pada tanggal 23 September 2016, "Salah satu warga Desa Watu Kecamatan Marioriwawo saat di temui di Kantor Dinas Kependudukan dan Catatan Sipil (Disdukcapil) Trans mengatakan sudah 3 hari dirinya mengurus E-KTP namun belum juga tuntas". Hal ini juga diperkuat dengan wawancara awal pada tanggal 20 Februari 2018 dengan salah seorang masyarakat yang berdomisili di Desa Patampanua Kecamatan Marioriawa, "mengatakan bahwa dirinya mengurus surat pindah domisili tapi tidak kunjung selesai dan hanya diberikan pernyataan oleh petugas di Dinas Kependudukan dan Pencatatan Sipil Kabupaten Soppeng untuk menunggu tanpa ada kejelasan yang pasti". Oleh karena itu, peneliti tertarik untuk melakukan penelitian dan mengkaji lebih dalam lagi mengenai efektivitas pelayanan publik pada Dinas Kependudukan dan Pencatatan Sipil Kabupaten Soppeng.

Tujuan penelitian dalam artikel ini adalah untuk mengetahui dan menjelaskan efektivitas pelayanan publik pada Dinas Kependudukan dan Pencatatan Sipil Kabupaten Soppeng. Adapun manfaat penelitian secara praktik adalah untuk memberikan informasi dan menambah wawasan berfikir dan bertindak para pelaksana atau pemberi layanan sehingga pelayanan dapat terlaksana secara efektif dan efisien. Sedangkan secara teoritis sebagai penambah wawasan berfikir bagi peneliti yang akan mengkaji tentang topik pelayanan publik.

\section{TINJAUAN PUSTAKA}

\section{Pelayanan Publik}

Kepmenpan

No.

63/KEP/

M.PAN/7/2003 mendefinisikan pelayanan publik sebagai segala kegiatan pelayanan yang dilaksanakan oleh penyelenggara pelayanan publik sebagai upaya pemenuhan kebutuhan penerima pelayanan maupun pelaksanaan ketentuan peraturan perundang-undangan. Sementara menurut perspektif kontrak sosial (dalam LAN, 2006), pelayanan publik adalah suatu proses kegiatan penyediaan pelayanan oleh pemerintah untuk memenuhi kebutuhan masyarakat yang pelaksanaannya dapat dilakukan oleh pemerintah sendiri dan/atau pihak swasta serta masyarakat.

Pasca otonomi daerah, desentralisasi kewenangan harus mampu mendorong terjadinya layanan publik yang lebih dekat dengan masyarakat yamg membutuhkan. Kebijakan publik yang dihasilkan diharapkan dapat memangkas rentang birokrasi yang panjang untuk menghindari penundaan dan penurunan kualitas dari layanan publik yang menjadi kewajiban negara kepada warganya. Keberhasilan proses desentralisasi dapat diukur dari kualitas layanan publik yang semakin baik. Kebijakan desentralisasi yang hanya dimaksudkan untuk menggantikan peran pemerintah pusat di daerah tanpa melakukan perubahan pada transaksi sosial yang terjadi, maka sangat sulit diharapkan terjadinya efek positif dari kebijakan publik tersebut. Oleh sebab itu perbaikan kualitas layanan publik menjadi faktor yang determinan dalam implementasi kebijakan desentralisasi. Terlebih pelayanan publik telah diamanatkan dalam Pembukaan UUD 1945 di alinea ke-4 (PKP2A II LAN, 2012).

Peraturan perundangan Indonesia telah memberikan landasan untuk penyelenggaraan pelayanan publik yang berdasarkan atas Asas-asas Umum Pemerintahan yang Baik (AAUPB). Pasal 3 Undang-Undang Nomor 28 Tahun 1999 tentang Penyelenggaraan Negara yang Bersih dari Korupsi, Kolusi dan Nepotisme menyebutkan asas-asas tersebut, yaitu asas kepastian hukum, transparan, daya tanggap, berkeadilan, efektif dan efisien, tanggung jawab, akuntabilitas dan tidak menyalahgunakan kewenangan. Asas-asas umum pemerintahan yang baik (algemene beginselen van behoorlijk bestuur) ini menjadi landasan dalam penyelenggaraan pelayanan publik. Penyelenggaraan pelayanan publik yang dilakukan oleh pemerintah masih dihadapkan pada sistem 
pemerintahan yang belum efektif dan efisien serta kualitas sumber daya manusia aparatur yang belum memadai. Pada saat ini persoalan yang dihadapi begitu mendesak, masyarakat mulai tidak sabar atau mulai cemas dengan mutu pelayanan aparatur pemerintahan yang pada umumnya semakin merosot atau memburuk. Pelayanan publik oleh pemerintah lebih buruk dibandingkan dengan pelayanan yang diberikan oleh sektor swasta, masyarakat mulai mempertanyakan apakah pemerintah mampu menyelenggarakan pemerintahan dan atau memberikan pelayanan yang bermutu kepada masyarakat. Hal ini terlihat dari masih banyaknya keluhan dan pengaduan dari masyarakat baik secara langsung maupun melalui media massa (Yosa, 2010).

\section{Efektivitas Pelayanan Publik}

Substansi pelayanan publik (dalam Mansyur, 2013) selalu dikaitkan dengan suatu kegiatan yang dilakukan oleh seseorang atau kelompok orang atau instansi tertentu untuk memberikan bantuan dan kemudahan kepada masyarakat dalam rangka mencapai tujuan tertentu. Pelayanan publik ini menjadi semakin penting karena senantiasa berhubungan dengan khalayak masyarakat ramai yang memiliki keaneka ragaman kepentingan dan tujuan. Dalam kaitannya dengan penyelenggaraan pemerintahan, birokrasi sebagai ujung tombak pelaksana pelayanan publik mencakup berbagai program-program pembangunan dan kebijaksanaan-kebijaksanaan pemerintah. Tetapi dalam kenyataannya, birokrasi yang dimaksudkan untuk melaksanakan tugastugas umum pemerintahan dan pembangunan tersebut, seringkali diartikulasikan berbeda oleh masyarakat. Birokrasi di dalam menyelenggarakan tugas pemerintahan dan pembangunan (termasuk di dalamnya penyelenggaraan pelayanan publik) diberi kesan adanya proses panjang dan berbelit-belit apabila masyarakat menyelesaikan urusannya berkaitan dengan pelayanan aparatur pemerintahan . Akibatnya, birokrasi selalu mendapatkan citra negatif yang tidak menguntungkan bagi perkembangan birokrasi itu sendiri (khususnya dalam hal pelayanan publik). Oleh karena itu, guna menanggulangi kesan buruk birokrasi seperti itu, birokrasi perlu melakukan beberapa perubahan sikap dan perilakunya antara lain :

1. Birokrasi harus lebih mengutamakan sifat pendekatan tugas yang diarahkan pada hal pengayoman dan pelayanan masyarakat; dan menghindarkan kesan pendekatan kekuasaan dan kewenangan

2. Birokrasi perlu melakukan penyempurnaan organisasi yang bercirikan organisasi modern, ramping, efektif dan efesien yang mampu membedakan antara tugastugas yang perlu ditangani dan yang tidak perlu ditangani (termasuk membagi tugas-tugas yang dapat diserahkan kepada masyarakat)

3. Birokrasi harus mampu dan mau melakukan perubahan sistem dan prosedur kerjanya yang lebih berorientasi pada ciri-ciri organisasi modern yakni : pelayanan cepat, tepat, akurat, terbuka dengan tetap mempertahankan kualitas, efesiensi biaya dan ketepatan waktu

4. Birokrasi harus memposisikan diri sebagai fasilitator pelayan publik dari pada sebagai agen pembaharu (change of agent ) pembangunan

5. Birokrasi harus mampu dan mau melakukan transformasi diri dari birokrasi yang kinerjanya kaku (rigid) menjadi organisasi birokrasi yang strukturnya lebih desentralistis, inovatif, flrksibel dan responsif.

Dari pandangan tersebut diatas, dapat disimpulkan bahwa organisasi birokrrasi yang mampu memberikan pelayanan publik secara efektif dan efesien kepada masyarakat, salah satunya jika strukturnya lebih terdesentralisasi daripada tersentralisasi. Sebab, dengan struktur yang terdesentralisasi diharapkan akan lebih mudah mengantisipasi kebutuhan dan kepentingan yang diperlukan oleh masyarakat, sehingga dengan cepat birokrasi dapat menyediakan pelayanannya sesuai yang diharapkan masyarakat 
pelanggannya. Sedangkan dalam kontek persyaratan budaya organisasi birokrasi, perlu dipersiapkan tenaga kerja atau aparat yang benar-benar memiliki kemampuan (capability), memiliki loyalitas kepentingan (competency), dan memiliki keterkaitan kepentingan (consistency atau coherency).

\section{PEDOMAN \\ UMUM \\ PENYELENGGARAAN PELAYANAN PUBLIK}

Keputusan Menteri Pemberdayaan Aparatur Negara No. 63 Tahun (2003) Tentang Pedoman Umum Penyelenggaraan Pelayanan Publik telah mengatur sejumlah prinsip dalam pemberian pelayanan publik. Prinsi-prinsip tersebut meliputi:

1. Kesederhanaan. Prosedur pelayanan publik tidak berbelit-belit, mudah dipahami dan mudah dilaksanakan

2. Kejelasan. Kejelasan yang dimaksud terdiri dari kejelasaan atas : (a) persyaratan teknis dan administratif pelayanan publik, (b) unit kerja/ pejabat yang berwenang dan bertanggung jawab dalam memberikan pelayanan dan penyelesaian keluhan/ persoalan/ sengketa dalam pelaksanaan pelayanan publik, dan (c) rincian biaya pelayanan publik dan tatacara pembayaran

3. Kepastian waktu. Pelaksanaan pelayanan publik dapat diselesaikan dalam kurun waktu yang telah ditentukan

4. Akurasi. Produk pelayanan publik diterima dengan benar, tepat, dan sah

5. Keamanan. Proses dan produk pelayanan publik memberikan rasa aman dan kepastian hukum

6. Tanggung jawab. Pimpinan penyelenggara pelayanan publik atau pejabat yang ditunjuk bertaggung jawab atas penyelenggaraan pelayanan dan penyelesaian keluhan/ persoalan dalam pelaksanaan pelayanan publik

7. Kelengkapan sarana dan prasarana. Tersedianya sarana dan prasarana kerja, peralatan kerja, dan pendukung lainnya yang memadai, termasuk penyediaan sarana teknologi telekomunikasi dan informatika (telematika)

8. Kemudahan akses. Tempat dan lokasi serta sarana pelayanan yang memadai, mudah dijangkau oleh masyarakat dan dapat memanfaatkan teknologi telekomunikasi dan informatika

9. Kedisiplinan, kesopanan dan keramahan. Pemberi pelayanan harus bersikap disiplin, sopan dan santun, ramah, serta memberikan pelayanan dengan ikhlas

10. Kenyamanan. Lingkungan pelayanan harus tertib, teratur, disediakan ruang tunggu yang nyaman, bersih, rapi, lingkungan yang indah dan sehat dilengkapi dengan fasilitas pendukung pelayanan, seperti parkir, toiet, tempat ibadah dan lain-lain.

\section{METODOLOGI PENELITIAN}

Jenis Penelitian yang digunakan dalam penelitian ini adalah penelitian deskriptif kualitatif (Creswell, 2013; Creswell \& Creswell, 2017; Creswell \& Poth, 2018). Penelitian deskriptif dipilih karena sesuai dalam proses pengumpulan data yang berkaitan dengan efektifitas pelayanan publik pada Dinas Kependudukan dan Pencatatan Sipil Kabupaten Soppeng. Dalam penelitian ini teknik pengumpulan data yang digunakan adalah teknik observasi, wawancara, dan dokumentasi. Informan penelitian adalah Kepala Dinas Kependudukan dan Pencatatan Sipil Kabuapten Soppeng, petugas pemberi pelayanan Dinas Kependudukan dan Pencatatan Sipil sebanyak 3 orang, dan masyarakat yang sedang mengurus administrasi kependudukan di Dinas Kependudukan dan Pencatatan Sipil Kabupaten Soppeng sebanyak 3 orang. Teknik pemeriksaan keabsahan data yang digunakan dalam penelitian ini yaitu teknik trianggulasi sumber. Adapun teknik analisis data yang digunakan dalam penelitian ini adalah model interaktif yaitu: 1) koleksi data, 2) reduksi data, 3) kondensasi data, 4) penarikan kesimpulan (Miles et al., 2014). 
HASIL PENELITIAN

PEMBAHASAN

Upaya pemerintah dalam memberikan pelayanan terbaik pada masyarakat tentunya membutuhkan indikator yang jelas dalam setiap aktivitas yang dilaksanakan. Oleh karena itu, dalam rangka memberikan penjelasan mendalam mengenai efektivitas pelayanan publik maka melihat berbagai aspek yang mampu menjawab dari permasalahan yang dihadapi. Adapun aspek yang menjadi fokus peneliti dalam melihat pelayanan publik yaitu: 1) prosedur pelayanan, 2) waktu penyelesaian pelayanan, 3) biaya pelayanan, 4) produk pelayanan, 5) sarana dan prasarana, 6) kompetensi yang dimiliki oleh petugas pelayanan. Dari keenam fokus penelitian ini menggunakan Keputusan Menteri Pemberdayaan Aparatur Negara No. 63 Tahun (2003) Tentang Pedoman Umum Penyelenggaraan Pelayanan Publik.

\section{Prosedur Pelayanan}

Prosedur pelayanan merupakan tahapan-tahapan dalam pelayanan publik yang dilakukan secara sistematis dan mudah dimengerti dalam proses pelayanan sehingga pelayanan publik menjadi efesien dan efektif. Pelayanan akan terasa mudah apabila prosedur pelayanan disusun sesederhana mungkin demi menunjang terciptanya pelayanan publik yang efisien dan efektif.

Upaya yang dilakukan peneliti dalam melakukan observasi di lapangan mengenai standar prosedur pelayanan, Dinas Kependudukan dan Pencatatan Sipil Kabupaten Soppeng belum menyediakan Papan Informasi mengenai alur prosedur pelayanan baik mengenai alur pelayanan Kartu Keluarga, Akta Kelahiran, Akta Kematian, E-KTP, dan sebagainya di Dinas Kependudukan dan Pencatatan Sipil Kabupaten Soppeng. Selanjutnya, belum tersedianya Papan informasi mengenai syarat-syarat kelengkapan berkas dalam mengurus administrasi kependudukan. Selain itu, prosedur pelayanan yang diterapkan belum terlalu memudahkan masyarakat, ini terlihat dengan loket pendaftaran dan verifikasi berkas berbeda dengan loket pengambilan berkas yang telah jadi sehingga masyarakat masih mondar-mandir ketika mengurus dokumen kependudukannya.

Berdasarkan hasil wawancara tentang Prosedur Pelayanan di Dinas Kependudukan dan Pencatatan Sipil Kabupaten Soppeng dengan masyarakat yang sedang mengurus dokumen kependudukannya dengan inisial IN yang mengatakan bahwa:

"Belum ada Papan Informasi kayaknya, mendaftar saja baru ambil nomor antrian saja baru ke sini lagi menunggu dan tingkat kemudahan dalam mengurus dan memenuhi persyaratan pelayanan mudah kayaknya"

(wawancara tanggal 04 Juni 2018, Pukul 11.10 WITA).

Pendapat tersebut, senada yang dikemukakan oleh informan BS yang sedang mengurus E-KTP, menyatakan bahwa:

"Pelayanan publik sangat perlu dalam penyediaan Papan Informasi karena kalau tidak maka pelayanan akan terkendala, ribet, tidak ngerti harus bertanya dulu kita mau dimana harus bawa berkas kemana. Apabila ada Papan informasi maka tidak perlu bertanya lebih detil kepada petugas"

(wawancara tanggal 04 Juni 2018, Pukul 11.10 WITA).

Selain tanggapan dari dua informan di atas, hal ini makin diperkuat dengan pernyataan masyarakat lain yang bernama Bapak Akmal (wawancara tanggal 04 Juni 2018, Pukul 11.20) yang mengatakan "Kalau di sini ngak ada ya, cuma pendaftar aja dan tingkat kemudahan dalam mengurus dan memenuhi persyaratan pelayanan cukup lumayan, mudah aja".

Dari hasil observasi dan wawancara dapat diketahui bahwa Dinas Kependudukan dan Pencatatan Sipil Kabupaten Soppeng telah memberikan kemudahan kepada masyarakat dalam pemberian pelayanan, namun masih perlu meningkatkan lagi prosedur pelayanan 
seperti disediakannya Papan Informasi mengenai alur prosedur pelayanan dan syarat-syarat kelengkapan berkas sehingga masyarakat yang kurang mengetahui dan gagap teknologi mampu segera mengetahui melalui papan informasi tersebut.

Prosedur pelayanan tentunya memberikan dampak terhadap pelayanan yang diberikan. Demikian halnya hasil penelitian yang telah diberikan kepada masyarakat telah sesuai dengan standar yang ditentukan. Hal ini sesuai dengan hasil penelitian yang mengungkapkan bahwa standar pelayanan merupakan patokan dasar dalam pelayanan terhadap aktivitas yang dilakukan guna pelayanan yang membahagiakan (Dahlan et al., 2017; Gani, 2014; Hasbi, 2016; Husain et al., 2015; Tahir, 2016).

\section{Waktu Penyelesaian}

Waktu penyelesaian merupakan waktu yang telah ditetapkan berdasarkan pada standar pelayanan yang berlaku atau standar operasional prosedur (SOP). sehingga pelayanan publik dapat terselesaikan tepat pada waktunya. Proses penyelesaian pelayanan publik, petugas dituntut menyelesaikan setiap jenis pelayanan dengan menggunakan waktu yang sesingkat mungkin agar masyarakat tidak menunggu terlalu lama dan masyarakat tidak terhalangi waktunya dalam mengurus setiap administrasi kependudukan.

Berdasarkan hasil penelitian yang diperoleh melalui observasi dalam standar waktu penyelesaian, Dinas Kependudukan dan Pencatatan Sipil Kabupaten Soppeng telah melayani dengan cepat dan maksimal, hal ini terlihat saat masyarakat mendaftar di loket pendaftaran terbilang cukup cepat, tetapi masih terdapat kekurangan yang terlihat pada penyelesaian dokumen kependudukan yang di mana masih terdapat dokumen kependudukan yang diurus oleh masyarakat tidak selesai tepat pada waktunya seperti yang terjadi pada pengurusan Kartu Keluarga yang diurus oleh masyarakat yang terkendala pada data penduduk di dalam database yang tidak ditemukan, E-KTP yang masih terbilang lama dalam proses perekaman penduduk yang diakibatkan sarana alat perekaman EKTP yang kurang, dan lain sebagainya sehingga masyarakat menunggu cukup lama.

Berdasarkan hasil wawancara tentang Waktu Penyelesaian di Dinas Kependudukan dan Pencatatan Sipil Kabupaten Soppeng dengan masyarakat yang sedang mengurus dokumen kependudukannya mengatakan bahwa: "Begitulah dari kebanyakan orang saja begitu, kalau banyak orang kan lama-lama dari faktor pengantrian begitu". Hal ini senada dengan yang dikemukakan oleh penerima layanan yang mengatakan bahwa pelayanan telah diberikan secara cepat, akan tetapi, menunggu antrian terlebih dahulu. Pendapat lain mengungkapkan bahwa "tingkat ketepatan waktu proses pelayanannya dilakukan secara cepat".

Menanggapi dari hasil wawancara dengan penerima pelayanan, maka petugas pemberi pelayanan Dinas Kependudukan dan Pencatatan Sipil Kabupaten Soppeng mengatakan "dalam memberikan pelayanan dilaksanakan sesuai dengan standar yag telah ditetapkan yaitu 5 menit bisa selesai. Akan tetapi, banyaknya masyarakat itu paling lama itu 7 menit sampai 8 menit". Selanjutnya petugas lain berpendapat bahwa pelayanan dilakukan tergantung dokumen kependudukannya itu kalau memadang datanya ini dikomputer sudah bagus tidak sampai 5 menit selesai tergantung datanya, akan tetapi data gandanya apakah ada perbaikanperbaikannya yang tidak lampirkan mereka harus minimal difoto atau kalau memang tidak bisa difoto harus kembali besoknya membawa itu berkas.

Berdasarkan hasil observasi dan wawancara dapat disimpulkan bahwa waktu penyelesaian pelayanan publik di Dinas Kependudukan dan Pencatatan Sipil Kabuapten Soppeng sudah cukup cepat, akan tetapi lama atau cepatnya penyelesaian administrasi kependudukan tergantung dari masyarakat sendiri sebagai pemohon. Hal utama yang sering menimbulkan keterlambatan adalah kekurangan kelengkapan berkas yang 
dibawa oleh pemohon sendiri sehingga membutuhkan waktu lebih dalam proses penyelesaian administrasi kependudukan yang diurus oleh masyarakat (Agi et al., 2015; Akhmad, 2016; Daraba, 2015; Nur, 2017).

\section{Biaya Pelayanan}

Biaya pelayanan merupakan segala bentuk biaya yang dibebankan kepada masyarakat saat melaksanakan pelayanan publik, biaya-biaya tersebut telah diatur dan ditetapkan sesuai dengan aturan yang berlaku sehingga tidak membebankan masyarakat dalam mengurus segala administrasi kependudukannya. Dalam proses pelayanan publik rincian biaya sangat penting untuk diminimalkan serendah mungkin sehingga masyarakat tidak merasa terbebani saat mengurus administrasi kependudukannya.

Hasil penelitian yang diperoleh melalui observasi dalam standar biaya pelayanan, Dinas Kependudukan dan Pencatatan Sipil Kabupaten Soppeng memberikan pelayanan dengan tidak memungut biaya atau gratis, sehingga masyarakat tidak perlu lagi menanggung biaya apa pun dan masyarakat tidak perlu lagi menggunakan calo dalam mengurus administrasi kependudukan. Hal ini sesuai dengan SOP yang telah di tetapkan. hasil wawancara tentang Biaya Pelayanan di Dinas Kependudukan dan Pencatatan Sipil Kabupaten Soppeng dengan masyarakat yang sedang mengurus dokumen kependudukannya beberapa penerima layanan yang telah diwawancara mengatakan bahwa "tidak terdapat biaya pelayanan administrasi”. Hal ini sesuai dengan RPJMD Kabupaten Soppeng tahun 2016-2021 yang bebas pungutan liar. Hal ini sesuai dengan beberapa hasil penelitian yang mengungkapkan bahwa penetapan standar biaya harus jelas, sehingga tidak terdapat kecurigaan antara penerima layanan dan pemberi layanan (Akhmad, n.d.; Anwar et al., 2017; Hamzah, 2016; Muliaty, n.d.; Paris, 2016; Prasodjo, 2017a; Wahyuni et al., 2017; Yusriadi \& Misnawati, 2017).

\section{Produk Pelayanan}

Produk pelayanan merupakan segala bentuk pelayanan yang dilakukan untuk menunjang segala bentuk kepentingan masyarakat. Produk pelayanan yang diberikan pemerintah bermacam-macam sesuai dengan kepentingan setiap masyarakat yang membutuhkan pelayanan, mulai dari administrasi kependudukan dan administrasi perizinan yang kesemuanya berhubungan dengan kubutuhan masyrakat akan pelayanan.

Hasil penelitian yang diperoleh melalui observasi dalam standar produk pelayanan, Dinas Kependudukan dan Pencatatan Sipil Kabupaten Soppeng menunjukkan bahwa semua bentuk administrasi kependudukan yang dibutuhkan oleh masyarakat dilayani oleh Dinas Kependudukan dan Pencatatan Sipil Kabupaten Soppeng seperti Pelayanan Penerbitan KTP, Pelayanan Penerbitan Kartu Keluarga, Pelayanan Penerbitan Akta Kelahiran, Pelayanan Penerbitan, Pelayanan Penerbitan Akta Kematian, Pelayanan Mutasi Penduduk/SKPWNI, dan Pelayanan Legalisasi Dokumen Kependudukan. Kesemua pelayanan tersebut yang sering masyarakat urus di Dinas Kependudukan dan Pencatatan Sipil Kabupaten Soppeng.

\section{Sarana dan Prasarana}

Sarana dan prasarana merupakan segala bentuk sarana dan prasarana yang dibutuhkan dalam menunjang segala bentuk dan jenis pelayanan sesuai dengan fungsi sarana dan prasarana tersebut. Dalam setiap penyelenggaraan pelayanan publik membutuhkan sarana dan prasarana yang memadai demi terciptanya pelayanan yang efektif dan efisien yang memuaskan bagi masyarakat saat menerima pelayanan.

Hasil penelitian yang diperoleh melalui observasi dalam standar produk pelayanan, Dinas Kependudukan dan Pencatatan Sipil Kabupaten Soppeng menunjukkan bahwa dari segi kebersihan ruang pelayanan setiap harinya bersih dan cukup nyaman, ini terlihat dari ruang pendaftaran yang memiliki tempat duduk untuk menunggu antrian yang memadai, tetapi sebaliknya dari segi kelengkapan 
fasilitas yang terdapat dalam ruang pelayanan masih terdapat kekurangan, ini terlihat dari masih kurangnya tempat duduk di tempat pengambilan berkas dan tempat parkir yang tidak beraturan serta tidak tersedianya kotak saran, kritik dan keluhan sehingga masyarakat yang kurang puas dengan pelayanan tidak dapat memberikan aspirasinya. Dari segi lingkungan yang aman bagi masyarakat selama di Dinas Kependudukan dan Pencatatan Sipil Kabupaten Soppeng telah tersedia Petugas Satpol PP yang berjaga di ruang pelayanan, akan tetapi di tempat Parkir belum adanya penjaga yang menjaga kendaraan masyarakat yang sedang mengurus dokumen administrasi kependudukan.

Berdasarkan hasil observasi dan wawancara dapat disimpulkan bahwa Dinas Kependudukan dan Pencatatan Sipil Kabupaten Soppeng telah menyediakan sarana dan prasarana yang dibutuhkan masyarakat, namun masih perlunya peningkatan dalam melengkapi sarana dan prasarana seperti penyediaan jasa fotocopy, papan informasi dan lahan parkir yang memadai harus dilengkapi demi terjaminnya kepuasan masyarakat dalam pelayanan publik. Dengan sarana dan prasarana yang memadai maka akan membantu masyarakat dalam menerima pelayanan yang maksimal (Isma et al., 2017; Prasodjo, 2017a, 2017b; Riyana, 2015; Saggaf et al., 2014; Salam, 2015; Wahyuni et al., 2017; Wulandari et al., 2018; Yusriadi \& Misnawati, 2017).

\section{Kompetensi Petugas Pemberi Pelayanan}

Kompetensi petugas pemberi pelayanan merupakan kemampuan yang harus dimiliki oleh seorang petugas pelayanan dalam melaksanakan semua tugasnya dalam penyelenggaraan pelayanan publik. Kompetensi petugas pemberi pelayanan harus ditetapkan dengan tepat berdasarkan pada keahlian, pengetahuan, sikap, keterampilan dan perilaku yang dibutuhkan guna terselenggaranya pelayanan publik yang efektif dan memuaskan bagi masyarakat.

Hasil penelitian yang diperoleh melalui observasi dalam standar kompetensi petugas pemberi pelayanan, Dinas Kependudukan dan Pencatatan Sipil Kabupaten Soppeng menunjukkan bahwa dalam proses pelayanan, petugas telah memberikan pelayanan dengan sopan dan santun, namun masih terdapat beberapa petugas yang kurang sopan saat melayani masyarakat, hal ini terlihat saat ada masyarakat yang bertanya namun dijawab dengan nada yang agak tinggi, dalam hal menjawab pertanyaan, pemberian informasi, dan kebutuhan yang berkaitan dengan pelayanan petugas menjelaskan dan mengarahkan masyarakat yang kurang melengkapi persyaratannya.

Dalam menyelesaikan dan menghadapi keluhan serta kesulitan dari masyarakat, petugas masih sering bingung jika terdapat data masyarakat yang tidak sesuai seperti nama penduduk yang tidak ada dalam Kartu Keluarganya sehingga petugas kesulitan untuk menambahkan nama penduduk yang tidak ada datanya dalam database. Kepedulian petugas untuk selalu mengutamakan kebutuhan masyarakat dalam pelayanan belum terealisasi dengan baik. Hal ini terlihat ketika ada masyarakat yang lupa mengcopy dokumen kependudukannya, petugas tidak memberi kemudahan bagi masyarakat dengan mengcopykannya pada printer All in One yang berada di ruang tersebut akan tetapi petugas menyuruh masyarakat untuk pergi mengcopy dokumen kependudukan tersebut di tempat Jasa Fotocopy. Dalam hal pemberian informasi terlihat kurang, ini nampak terlihat pada bagian Center Informasi yang tidak adanya petugas yang siap melayani pada bagian tersebut dan dari segi kerapihan masih terdapat beberapa petugas yang melayani masyarakat dengan menggunakan sandal.

Hasil obsevasi dan wawancara dapat disimpulkan bahwa Petugas Pemberi Pelayanan Dinas Kependudukan dan Pencatatan Sipil Kabupaten Soppeng telah memberikan pelayanan yang cukup baik kepada masyarakat, namun masih terdapat kekurangan yang perlu dibenahi seperti kerapian dan kesopanan petugas pemberi pelayanan agar bersifat profesional saat melayani masyarakat sehingga tidak ada 
lagi petugas yang menggunakan sandal dan bermain handphone saat melayani masyarakat. Hal ini sesuai dengan berbagai hasil penelitian yang mengungkap bahwa kompetensi petugas tentunya merupakan hal yang sangat urgen dalam memberikan pelayanan. Dengan kompetensi yang dimiliki oleh petugas pelayanan maka akan masyarakat merasa terlayanani sesuai dengan standar yang telah ditetapkan (Akib \& Salam, 2016; Isma et al., 2017; Mirdawati et al., 2018; Saggaf et al., 2014; Salam, 2015).

\section{KESIMPULAN}

Berdasarkan hasil penelitian yang telah dilakukan mengenai efektifitas pelayanan publik pada Dinas Kependudukan dan Pencatatan Sipil Kabupaten Soppeng bahwa Pelayanan Publik yang diselenggarakan sudah baik akan tetapi masih perlu adanya peningkatan, penambahan infrastruktur yang menunjang pelayanan dan perubahan sistem pelayanan yang lebih memudahkan lagi masyarakat dalam mengurus administrasi kependudukan sehingga dapat disimpulkan bahwa pelayanan publik pada Dinas Kependudukan dan Pencatatan Sipil Kabupaten Soppeng sudah berjalan dengan efektif namun dengan beberapa catatan perbaikan, karena masih ditemukan beberapa permasalahan. Hal ini terlihat dari beberapa permasalahan dalam proses penyelenggaraan pelayanan publiknya, yang antara lain; 1) Standar pelayanan publik yang belum dapat diterapkan secara konsisten, 2) Profesionalisme Aparat Sipil Negara / petugas pelayanan yang masih rendah, 3) Belum memadai sarana dan prasarana dalam pelaksanaan pelayanan publik, 4) Kesadaran masyarakat masih rendah terhadap pentingnya kepemilikan dokumen kependudukan, 5) Masih banyak penduduk non permanen yang belum melakukan perekaman data di akibatkan tingginya mobilitias penduduk, 6) Kebutuhan masyarakat terhadap pelayanan dokumen administrasi kependudukan yang profesional dan cepat.

\section{REKOMENDASI}

Upaya memaksimalkan pelayanan public harus memberikan pelayanan yang membahagiakan dengan menyediakan standar operasional prosedur (SOP) yang jelas yang ditunjang dengan ASN yang memadai. Selanjutnya, memberikan pemahaman kepada masyarakat terhadap pelayanan yang disampaikan. Selain itu, harus ditunjang oleh Sarana dan prasarana yang memadai. Hal yang paling menentukan adalah dibutuhkan pemimpin yang visioner yang mampu memberikan pelayanan public kepada masyarakat.

\section{DAFTAR PUSTAKA}

Agi, A. A., Kahar, F., \& Akib, H. (2015). Persepsi Mahasiswa Pendidikan Administrasi Perkantoran Tentang Pelayanan Administrasi Akademik pada Biro Administrasi Akademik dan Kemahasiswaan Universitas Negeri Makassar. Jurnal Office, 1(2), 192-197.

Akhmad, A. (n.d.). Studi Pengembangan Kemampuan Sumber Daya Manusia Dalam Pelayanan Publik Di Kantor Pelayanan Terpadu Kabupaten Jeneponto. Jurnal Ilmiah Ilmu Administrasi Publik, 6 (2), 136849.

Akhmad, A. (2016). Pengaruh Profesionalisme Sumber Daya Manusia terhadap Kinerja Pelayanan di Kantor Samsat Pinrang. Jurnal Office, 2(2), 103108.

Akib, H., \& Salam, R. (2016). Analisis Kualitas Pelayanan Publik Berbasis Importance Performance Analysis (IPA) pada Kecamatan Kota Makassar. Jurnal Ilmiah Scientific Pinisi, 2(April 2016), 1620.

Anwar, H., Niswaty, R., \& Saleh, S. (2017). Pelayanan Penerbitan Buku Pelaut Berbasis Online. Jurnal Ilmiah Ilmu Administrasi Publik, 7(1), 11-24.

Astuti, E. P., \& Amalah, N. (2020). Effect of Work Discipline on employee performance in the Office of Public Appraisal 
Services Herly, Ariawan and Partners. PINISI Discretion Review, 1(2), 39-46.

Creswell, J. W. (2013). Research Design: Qualitative Approach, Quantitative and Mixed. Yogyakarta: Student Library.

Creswell, J. W., \& Creswell, J. D. (2017). Research design: Qualitative, quantitative, and mixed methods approaches. Sage publications.

Creswell, J. W., \& Poth, C. N. (2018). Qualitative inquiry Research Design Choosing Among Five Approaches (Vol. 53, Issue 9). SAGE Publications Ltd. https://doi.org/10.1017/

CBO9781107415324.004

Dahlan, D., Hasim, D., \& Hamdan, H. (2017). Pengaruh Manajemen Sumber Daya Manusia dan Budaya Organisasi Terhadap Kualitas Pelayanan Pada Kantor Kecamatan Tamalate Kota Makassar. Jurnal Ad'ministrare, 4(2), 69-75.

Daraba, D. (2015). Penerapan Prinsip Pelayanan Administrasi Pada Kantor Desa Panciro Kecamatan Bajeng Kabupaten Gowa, Indonesia. Jurnal Office, 1(2), 185191.

Gani, F. S. (2014). Respon Masyarakat Terhadap Kinerja Pelayanan Publik Di Kantor Kecamatan Pinogaluman. Jurnal Ad'ministrare, 1(1), 62-71.

Hamzah, O. S. (2016). Perilaku Birokrasi Pemerintah Dalam Pelayanan Puskesmas di Kota Makassar. Jurnal Ilmiah Ilmu Administrasi Publik, 4(1), 30-45.

Haprabu, W., Daswati, D., Ahmad, A., \& Salam, R. (2020). Quality of Driving License Service at the Palu Police Station. PINISI Discretion Review, 1(1), 1-6.

Hasbi, M. (2016). Aktualisasi Sinergitas Komponen Governance dalam Peningkatan Pelayanan Pendidikan Kecakapan Hidup di Kota Makassar. Jurnal Ad'ministrare, 3(1), 1-16.
Husain, L., Amirullah, A. H., \& Saleh, S. (2015). Efektivitas Pelaksanaan Pelayanan Kearsipan Pada Dinas Pendidikan Provinsi Sulawesi Selatan. Jurnal Ad'ministrare, 2 (1), 46-52.

Isma, E. W., Darwis, M., Saleh, S., \& Salam, R. (2017). Kualitas Pelayanan Administrasi pada Puskesmas Gattareng Kecamatan Gantarang Kabupaten Bulukumba. JURNAL ILMU ADMINISTRASI PERKANTORAN (JIAP), 21-28.

Jamaluddin, J., Saggaf, S., \& Rahayu, S. (2017). Kedisiplinan Aparatur Sipil Negara pada Kantor Badan Kependudukan dan Keluarga Berencana Nasional Provinsi Sulawesi Selatan. Jurnal Ilmiah Ilmu Administrasi Publik, 7(1), 25-29.

Keputusan Menteri Pemberdayaan Aparatur Negara. (2003). Keputusan Menteri Pemberdayaan Aparatur Negara No. 63 Tahun 2003 Tentang Pedoman Umum Penyelenggaraan Pelayanan Publik.

Labiran, M. (2013). Analisis Penerimaan Daerah Dari Sektor Pariwisata Di Kabupaten Tana Toraja Dan FaktorFaktor Yang Mempengaruhinya. Skripsi Fakultas Ekonomi dan Bisnis. Jurusan Ilmu Ekonomi. Makassar ....

Mansyur, Sastrio. 2013. Efektivitas Pelayanan Publik dalam Perspektif Konsep Administrasi Publik. Jurnal ACADECA Fisip Untad. Volume 05, Nomor 01, Februari 2013.

Miles, M. B., Huberman, A. M., \& Saldana, J. (2014). Qualitative data analysis: A method sourcebook. In $C A$, US: Sage Publications.

Mirdawati, J., Niswaty, R., Darwis, M., \& Salam, R. (2018). Keefektifan Pelayanan IMB Pada Kantor Dinas Penanaman Modal dan Pelayanan Terpadu Satu Pintu Kota Makassar The effectiveness of IMB Services at the Makassar City Investment Office and One Door Integrated Services at Makassar City. 
Muliaty, M. (n.d.). Faktor-faktor Yang Mempengaruhi Kualitas Pelayanan Pada Politeknik Negeri Media Kreatif Makassar. Jurnal Ilmiah Ilmu Administrasi Publik, 6 (1), 97765.

Nur, M. (2017). Kualitas Pelayanan Prima pada PT PLN (Persero) Rayon Makassar Selatan. Jurnal Office, 3(1), 72-78.

Paris, Y. (2016). Pengaruh Pelayanan Bidang Penerbitan Sertifikat Tanah Terhadap Kepuasan Masyarakat Pada Kantor Badan Pertanahan Nasional Kota Makassar. Jurnal Ilmiah Ilmu Administrasi Publik, 4(1), 65-83.

Prasodjo, T. (2017a). Paradigma Humanis dalam Pelayanan Publik. Jurnal Ilmiah Ilmu Administrasi Publik, 7(1), 38-45.

Prasodjo, T. (2017b). Pengembangan Pariwisata Budaya dalam Perspektif Pelayanan Publik. Jurnal Office, 3(1), 712.

Riyana, C. (2015). Peranan Teknologi dalam Pembelajaran. Pengembangan ICT Dalam Pembelajaran. https:// doi.org/10.1016/j.revmed.2010.08.003

Rizqulloh, F., \& Elida, T. (2015). Pengaruh Kualitas Pelayanan, Word of Mouth, dan Loyalitas Pelanggan Terhadap Niat Pembelian Kembali pada Bukalapak.com. Jurnal Ilmiah Ekonomi Bisnis.

Saggaf, S., Salam, R., Kahar, F., \& Akib, H. (2014). Pelayanan Fungsi Administrasi Perkantoran Modern. Jurnal Ad'ministrare, 1(1), 20-27.

Salam, R. (2015). Pelayanan Fungsi Administrasi Perkantoran Modern Sebagai Basis Persaingan Masyarakat Ekonomi Asean (MEA) 2015. Seminar Nasional Dies Natalis UNM Ke-54 "Peran Pendidikan Karakter Melalui Optimalisasi IPTEK Pencerdasan Generasi Unggul.

Sedarmayanti. (2017). Manajemen Sumber Daya Manusia. In Manajemen Sumber
Daya Manusia.

Sunarsi, D., \& Baharuddin, A. (2019). The Effect of Service Quality and Price Accuracy on Consumer Confidence and Implications for Sales Increase. PINISI Discretion Review, 3(2), 101-110.

Sunusi, S. (2016). Determinan Implementasi Kebijakan Pengembangan Sumber Daya Aparatur Pemerintah Daerah Kabupaten Sidenreng Rappang. Jurnal Ilmiah Ilmu Administrasi Publik, 6(1), 61-68.

Tahir, N. (2016). Motivasi Kerja Pegawai Dalam Pelayanan Publik di Sekretariat Pemerintah Daerah Kabupaten Takalar. Jurnal Ad'ministrare, 3(2), 1-10.

Wahyuni, N., Akib, H., \& Darwis, M. (2017). Keefektifan Pelayanan Kartu Tanda Penduduk Elektronik (KTP-EL). Jurnal Ilmiah Ilmu Administrasi Publik, 7 (1), 1-10.

Wardhani, A. P., Hasiolan, L. B., \& Minarsih, M. M. (2016). Pengaruh Lingkungan Kerja, Komunikasi dan Kepemimpinan Terhadap Kinerja Pegawai ( Studi kasus di Dinas Kebudayaan dan Pariwisata Kota Semarang). Journal of Management.

Wulandari, F. A., Sakawati, H., \& Akib, H. (2018). Pelayanan Klaim Peserta Badan Penyelenggara Jaminan Sosial Ketenagakerjaan Pada Kantor BPJS Ketenagakerjaan Kota Makassar. UNIVERSITAS NEGERI MAKASSAR.

Yusriadi, Y., \& Misnawati, M. (2017). Reformasi Birokrasi Dalam Pelayanan Publik (Studi Pelayanan Terpadu Satu Pintu). Jurnal Ilmiah Ilmu Administrasi Publik, 7(2), 99-108. 